\title{
Does School-Feeding Initiative Matter? An assessment of Its Impact on Quality Education and Positive Behavior Change of Learners in Primary Schools of Chipata District of Zambia
}

\author{
John Zimba* \\ Anoya Zulu Day Secondary School, Chipata - Zambia
}

*Corresponding Author:John Zimba, Anoya Zulu Day Secondary School, Chipata - Zambia

\begin{abstract}
This research article investigates the impact of school feeding programs in schools on education quality in Zambia. A case study of two primary schools were sampled with all class teachers from Grades 1 to 7 as participants. It also included one administrator from the respective schools and one representative from the organisation funding the program. Theresearch articledraws from a rights based understanding of quality education and the conceptualization of educational quality from the social justice perspective.A mixed method approachwas used to carry out the study. The findings showed that school feeding initiative does positively influence leaner behavior but it has less impact on quality education. The article concludes by proposing that more sustainable locally based solutions should be explored and adopted while the school feeding model propelled by donor aids should be redesigned to promote quality education rather than its current restricted role. Thisis because of the persistent question of donor aid sustainability as experienced from the previous interventions. Crucially important is government's role in meeting the education quality indicators which still remain a huge challenge and undermines its ability to achieving the SDGs 2030.
\end{abstract}

\section{INTRODUCTION}

The concept of universal access to quality education has for long been misunderstood for quantitative enrolment within the education discourse.The declaration of education for all (EFA) during the Jomtein Conference in 1990 led to many African countries embarking on massive enrolment of pupils in schools while quality educationwas largely disregarded (Barrett, 2011).Apparently, educational commentators argue that what matters most is not mere enrolment in schools, but quality of learning process taking place.Exacerbated by rapid population growth in the $90 \mathrm{~s}$, UN calls for universal access to education led toincreased demand for education enrollment in schools. Unfortunately,many subSaharan countrieswere pushed to breaking points in enrollingchildren into school (UN, 2014). For instance, Kelly (1996) argues, the declaration led to massive crisis in schoolsas observed from limited access to quality educationand financing.Admittedly, differences in histories between and among countries in terms of political will, economic growth, cultural, meant that most of these targets were set without considering all these dynamics and making implementation of the recommendations a difficult task for some countries (Unterhalter, 2014; Miles and Single, 2010).In Zambia,increased pupil absenteeism and dropout in primary schools remained a challenge. Pupil drop out was at $2.27 \%$ for primary schools between grades 1 to 7 with seemingly poor quality education still on the rise (MOE, 2007). This was despite having numerous community based organisations coming on board to help ameliorate this problem. With the advent of post-2015 agenda in UN report (2015), the narrative has however shifted from EFA to a new campaign which is 'No one is left behind'. The report forcibly challenge member countries to address the problem of gender parity and quality education in the outlined Sustainable Development Goals (SDGs) 2030.Critical in this discussion, the article will belooking at quality education in terms of how learning and teaching is taking place in marginalized communitiesas currently observed(Verger et al. 2015).

Driven by the Universal Declaration of Human Rights (UDHR) in 1948 for an inalienable right of every child to a quality education as well as the conceptualization of educational quality drawn from social justice perspective as argued byUnterhalter and Brighouse (2007), I intend to explore this study as follows: Firstly, a closer screening of quality education provision through the lens of Zambian 
Government's adoption of the EFA policy and its 2015 MDGs accomplishments. Crucially importantly is the second part of linking this goal to SDGs of the UN agenda 2030 of "No one is left behind" as reflected in the United Nation's Report (2015). This means debating the policy in the context of Human Rights perspective.A background check of the current government policies being implemented will be assessed based on the current SDGs as built fromthe 2015MDGs quality indicators. The 'quality standards' in this article will refer to all inputs that promote quality; teacherpupil ratio, class size and availability of learning and teaching materials.In summary, this paper will also delve into an in-depth critical analysis of the MDGs and role of donor aid in education. The apex of the discussion will be the findings of the research study, its recommendationsand conclusions towards the end.

\subsection{Rights-Based and Social Justice Perspective on Education}

The right based approach is more interested with the intrinsic value of education but also not neglecting the quality educational processes. This is in light of the fact that beyond the right to education and other outcomes key to achieving other rights, rights-based seek to protect children's rights while in education (Subrahmanian 2002; Pigozzi 2008).The UNICEF report (2008) posits that children have a legal right to education of an acceptable quality and that which adapts to the real needs of individual child. The UNESCO Convention 1989 on the rights of every child, accessing quality education isunderstood in the context of giving every child the right to a free and compulsory primary education. The essence is that education should focus on full human development, strengthen respect for human rights, and promote understanding, tolerance and friendship (UDHR Article 26) in (United Nations, 1989). Therefore, quality education according to Schweisfurth(2014: 260) "ensures that the teaching and learning adopts a multiple perspective that acknowledges multiple interactions within and beyond the classroom which shapes individual identities and social worlds". This is in contrast to what is practised in the Zambian schools as observed from the SAMEQ reports (2011). Nevertheless, Alexander (2008a, 2014) in Schweisfurth (2014) has argued that education quality was misunderstood by many as being the outcome rather than the processes that take place in a classroom environment.UNESCO (2014) acknowledges that 250 million children in schools have not acquired the basic literacy and numeracy skills. On the contrary, there is a global depiction according to Schweisfurth (2014) and UNESCO (2013) that the understanding of good quality is perceived as practice of equipping people with the relevant skills and attitudes, as well as obtaining descent work and other gains. Alexander (2014) points out that it is this depiction that has led to some unintended consequences on educational quality as countries get engrossed with the prescribed global measurements and measurability such as the new PISA TEST for measuring progress, while silencing what good teaching and learning ought to be and how it could be promoted and evaluated.

\subsection{Formation and Critique of Formulation of MDGs}

This partcritically looks at the background of the formulation of MDGs in Zambia and the impact that national policies influenced by the MDGs have had on the quality of education until 2015. It also connects this review to the post 2015 agenda envisaged within the SDGs. Therefore, education quality will be explained in the context of quality indicators as outlined in the introduction.

National debate on qualityeducation tends to be highly politicised and often with the involvement of international advocacy groups and NGOs (HakiElimu 2000; Mundy and Murphy 2001).However, the big question for the Zambian government is whether it undertook a right course of action from the preamble in providing quality education. For instance, NGOs have in the last two decades claimed to help marginalised communities access quality education (MOE, 1996 and MOE 2010). The daunting question is whether this is the sort of helpneededto achieve quality EFA goal.

According to Unterhalter (2014), there was a general consensus by member countries at the Jomtein Conference in 1990 on the need to meet the basic learning needs, equity and quality for all school going children. This was further reiterated at the Dakar Conference in 2000 in Senegal, in which a framework design of six goals was tabled (Dakar Framework Report, 2000). In response to the Jomtien recommendations, Zambia drew up a roadmap on how it was going to implement the six goals. For example, some measures included massive teacher recruitment, construction of more schools as well as expanding on the existing school infrastructure (MOE, 1996). Moreover, according 
to JCTR report (2005), the government claimed that education enrolment for girls and boys between 1990 and 2000 was about $69 \%$ and $71 \%$ respectively, with the potential to attain a $100 \%$ enrolment by 2015. In fact, the UNDP (2003) in JCTR (2005) reported that Universal Primary Education was one of the MDGs likely to be achieved by the country. However, the crucial question is ascertaining whether these measures were adequate enough to meet the definition of quality education.

Schweisfurth (2014) acknowledges that the Learner-Centred Education (LCE) is the way to achieving quality education even though the education funders such as International agencies tend to come up with their own criteria of measuring quality education. Unfortunately, theirstandard measurements tend to get the endorsement of the global approval. For example, these reform policies may include changes in the curriculum and may also be triggered by the LCE, but they tend to be hurriedly implemented by many countries without taking cognizance of other barriers such as timeframe, accessibility to learning and teaching materials, teacher capacity limited by training as well as lack of personal experience as evidenced from the case of least developed countries (Brundrett, 2014). SACMEQ $(1998 ; 2007)$ posits that while acknowledging that teacher training and experience was critical to improving the professional development and application of the pedagogical skills, the findings show that about $49.3 \%$ of teachers had not completed Grade 12 in Zambia which is a prerequisite for entry into college. At the same time, while the years required for a full teacher training remained at 2 years, the average teaching experience on the contrary dropped from 11.5 years to 6 years. Theimplication of this was that many teachers were young and inexperienced.

According to the MOE (2009), the schools by 2007 were not properly equipped with teaching and learning materials. This as reported by SAQMEQ $(2007 ; 2011)$ is assumed to have been exacerbated by the government declaration of free basic education in 2002 which led to the unprecedented enrolment levels beyond the available classroom spaces and an abnormal teacher-pupil ratio. This was a regional problem for sub-Saharan countries which embarked on free primary education policy in an attempt to provide universal primary education. Consequently, such policies became unsustainable and school completion remained a challenge (Abuya et al., 2013). For example, Brundrett (2014) notes that in the case of developing countries, less than 60 per cent of primary schools enrolled in grade one went all the way to completing the last grade. Ostensibly, the World Bank triggered this problem indirectly when it emphasised on the need for children to complete universal primary education on the basis that it provided the best rate of returns for investment in the human capital (Heyneman, 2003; 2004).

The Zambian government got into this pitfall as the move to declare free access to basic education for all was immediately confronted by a financial crisis which forced government to impose a teacher employment freeze in 2004. This was amidst the already fewer teachers who later on became overwhelmed with huge numbers in classrooms (SAQMEQ, 2007). This is what Waage et al. (2010) argues that the MDGs merely created unbearable pressure on countries which eventually resorted to presenting aggregate gains enrolment rates, while shielding inequalities in the distribution.

Unfortunately, this pressure being exerted on countries to provide EFA in order to meet the MDGs has had some unintended consequences. For example, Tungaraza et al. (2015) argue that little attention has been paid towards monitoring quality and relevance of the education being offered in schools. Ironically, Barret et al. (2014) and UNESCO (2012) observed that while the EFA has been one of the central issue in the MDGs for the past 15 years, with the past 25 years focusing on expansion of primary education, a sharp contrast still exists. For example, overwhelming evidence shows children leaving primary education still display literacy challenges. Schweisfurth (2014) noted that by the turn of the Millennium, about 157 million children of school going age were not in school as the pre-occupation of the global agenda was heightened on promoting access to basic education. Therefore, it is the more reason that focus in the post-2015 should be more on learning that takes place within school unlike in the past where the focus has been on pupil access to school. (Barret et al., 2014)

In view of this, both UNESCO and UNICEF (2013) have argued that the cracks in the current global education agenda were due to lack of clear articulation between the EFA and MDG processes and the need for the two to effectively integrate. Even though this claim gives a plausible explanation, there is still a danger of replicating the same outcomes in the next SDGs, as long as the International Agencies 
continue to hold the definition of education in their own context as observed by Tabulwa (2003) in (Schweisfurth, 2014). In fact, Hulme (2010) and Robert, (2005) in Unterhalter (2014) argues that while the Dakar framework for EFA was a product of wider consultation of key stakeholders such as government, civil society or EFA movements, the MDG framework was exclusively driven by a small powerful group of the International Agencies such as the World Bank that dominated and prioritised its agenda. The MDG as argued by Unterhalter (2014) focused on ensuring everywhere, boys and girls completed a full course of primary schooling, while school attendance, participation and learning gains had little bearing in shaping this policy frame.

In the case of Zambia as reported in SACMEQ (2007), government claimed to have addressed all phases of schooling at all levels including the cross-cutting issues of gender, HIV and AIDS and those requiring special educational needs (SEN). However, this does not settle the question of quality education for all, when the country still has barriers to dismantle which inhibits this educational quality provision. For example, SACMEQ report (2011) highlights that about $19.5 \%$ of schools in the country needed complete rebuilding while $43.3 \%$ needed major repairs. The report further highlights that pupil sitting and writing space was only $78.5 \%$ by 2007 while the standard learning hours were curtailed from five to four a day for Grade six pupils.

Everything said and done, it is encouraging that the new roadmap envisaged in the SDGs 2030 could be a turnaround in the quest for quality education in all schools. The popular slogan within the SDG'No one is left behind' will compel government to put up measures that would promote quality education.It is crucially important to note that the SDG has become an appendage of the MDGs 2015, but the distinctiveness is its broader scope. SDGs seek to address the contemporary issues of exclusion in form of gender equality and reduced inequality within and between countries UN (2015).

\subsection{Donor Aid on Education in the 21st Century}

Thereis increasing debate among researchers and policy makers regarding the impact of donor aid on education in Africa. While certain quarters argue donor aid is yielding positive results in transforming people's livelihood, critics argue it is not. There is a claim that resources offered by community-based organisations offer little help if anything in changing the course of quality education offered in schools (Munteanu et al., 2014). For instance, Moyo (2010) argues donor aid is responsible for pushing countries into downward spiral of poverty as nations descend to a vicious cycle of aid. While this could be a shrewd argument, the impact of donor aid in promoting equity access to education in developing countries cannot be ignored. In as much as donor aid has enabled the flow of resources for education resulting in improvededucational provision in Zambia since 1990s, the challenge has been responding to the donor's requirements MOE (1996).Admittedly, donor's requirements tend to focus more on the donor perception than perceived needs within the Ministry of Education. This is coupled with the absence of effective coordinating mechanism to establish a clear roadmap for donor involvement at every level of education within the agreed standards and implementation procedures Kelly (1999). According to CSPRreport (2005:7) "donor pledges must be based on MDG financing requirements, with sets of conditions jointlynegotiated with the Government of the Republic of Zambia (GRZ) and domestic stakeholders in the development process. Thoseconditions should be aligned with country-owned development priorities. And donorpledges should be met with timely and full disbursements". However, this is not to ignore the significant role donor aid plays in the education of the country.

\section{RESEARCH DESIGN AND METHODOLOGY}

In conducting this research, a mixed-method approach was adopted as influenced by the research questions. Most importantly, the two methods complement each other in giving statistics and providing in-depth explanations behind the underlying assumptions. A case study of two primary schools within Chipata Town of Eastern Province involved in feeding program were selectively picked. Given that the feeding program is being implemented in schools with similar characteristics of leaners within the province, findings from two schools could as well be generalized to other schools. In fact, generalisation is a unique strength of a case study approach as argued (Punch 2009). The sample consisted of all class teachers from Grade 1 to 7 and a school administrator from each school. One participant from the organisation in-charge of the school feeding programs was includedto get the perceptive of the donor funder on the program initiative. Teachers were involved because they make 
an extremely important part of this study in terms of feedback on the policy success. They are the end user in the policy implementation as they are in the frontline. Both qualitative and quantitative data were collected. For instance, quantitative data was collected using self-administered questionnaires while qualitative data was collected using semi-structured interviews.Teachers were asked to fill-in the questionnaires while school administrators and a representative from an NGO had an exclusive one-to-one interview. Questions were framed to bring out perspectives on whether the feeding program was an appropriate intervention for rural and peri-urban public schools in improving pupil attendance and quality education. Qualitative data was analysed using themes while quantitative one was analysed using SPSS. The next section presents findings and discussion.

\section{RESEARCH FINDINGS AND DISCUSSION}

Thissection presentsfindings based ondata collected and analysed from statistics and emerging themes as observed from participants' narratives and responses.

\subsection{Teacher's Knowledge about Pupil's Background and Attendance}

The first set of questions were asked to explore class teacher's knowledge depth about pupils' personal characteristics and background. For example, this was about drawing out information about the socio-economic background of pupils, attendance and dropout rates. Generally, $65 \%$ of the pupils in these schools come from disadvantaged families and 35\% from middle class.Disadvantaged backgrounds in the Zambian context include those parents that earn below the poverty datum line which less than a US dollars per day as set by UN report. Any family that lives on less than a dollar which apparently has been raised to USD 1.90 is considered as poor according to the recent UNDP report (2016).Pupils' attendance was fairly good as noticed from teachers' responses with the majority sharing opinions between either good or very good as seen below:

Table1.How is pupil attendance in your class?

\begin{tabular}{|l|l|l|l|l|l|}
\hline \multicolumn{2}{|c|}{ Frequency } & \multicolumn{1}{c|}{ Percent } & \multicolumn{1}{c|}{ Valid Percent } & Cumulative Percent \\
\hline \multirow{3}{*}{ Valid } & Very Good & 3 & 21.4 & 21.4 & 21.4 \\
\cline { 2 - 6 } & Good & 10 & 71.4 & 71.4 & 92.9 \\
\cline { 2 - 6 } & Poor & 1 & 7.1 & 7.1 & 100.0 \\
\cline { 2 - 6 } & Total & 14 & 100.0 & 100.0 & \\
\hline
\end{tabular}

However, despite the proclamation of free primary education, the problem of pupil dropout still exists with $36 \%$ of the sample acknowledging having recorded cases of pupil dropout. Several factors were raised behind this problem: economic if reasons for dropping out were financially related; culturally if reason were associated with cultural practice and other traditional norms; behaviorally if reasons were psychologically linked. All the categories mentioned were at play although cultural and behavioralfactors were the leading cause as observed below

Table2.Reasons for pupil dropout of school

\begin{tabular}{|l|l|l|l|l|l|}
\hline \multicolumn{2}{|c|}{ Frequency } & Percent & Valid Percent & Cumulative Percent \\
\hline \multirow{4}{*}{ Valid } & Economical & 1 & 7.1 & 20.0 & 20.0 \\
\cline { 2 - 6 } & Cultural & 2 & 14.3 & 40.0 & 60.0 \\
\cline { 2 - 6 } & Behavioral & 2 & 14.3 & 40.0 & 100.0 \\
\cline { 2 - 6 } & Total & 5 & 35.7 & 100.0 & \\
\hline Missing & System & 9 & 64.3 & & \\
\hline Total & 14 & 100.0 & & \\
\hline
\end{tabular}

\subsection{Assessing the Impact of Feeding Program on Pupil Behavior}

The questions under this category were phrased to assess the impact of the feeding program on pupils from teachers' perspective. In the first place, when the sponsor was asked to explain the objective of the feeding program in schools, this was the response:

We're targeting to improve enrolment, attendance and learner participation in class...so we're running this project in 98 schools in Eastern Province....the program running since 2014.

In trying to assess the impact of the program, one area of investigation was to find out how this program changed pupil attendance in class. There was an overwhelming response among participants 
Does School-Feeding Initiative Matter? An assessment of Its Impact on Quality Education and Positive Behavior Change of Learners in Primary Schools of Chipata District of Zambia

with $71 \%$ showing it greatly improved in contrast to $29 \%$ who indicated there was moderate improvement.

Table3.How has feeding program changed pupil attendance in your class?

\begin{tabular}{|c|l|l|l|l|l|}
\hline \multicolumn{2}{|c|}{} & Frequency & Percent & Valid Percent & Cumulative Percent \\
\hline \multirow{3}{*}{ Valid } & Greatly improved & 10 & 71.4 & 71.4 & 71.4 \\
\cline { 2 - 6 } & Moderately Improved & 4 & 28.6 & 28.6 & 100.0 \\
\cline { 2 - 6 } & Total & 14 & 100.0 & 100.0 & \\
\hline
\end{tabular}

Apparently, all participants unanimously confirmed that the program had imparted a positive behavioral change attitude on learners, although a small fraction of $30 \%$ of the participants indicated that the program was not responsible for improved performance in class. For instance, $70 \%$ of participants observed pupil returned to school after introduction of the feeding program. In response to the question about the significance of the program on pupil behavior, the response from the director of the program was as follows:

School heads have shared stories of improved attendance.... we've learnt about the same in our impact assessment survey....there is significant increased enrolment, improved attendance, improved classroom participation by leavers.

In support of this verbatim, a vast majority of participants over $70 \%$ held the view that withdrawing the feeding program would massively lead to increased absenteeism. This opinion was equally echoed among the two school administrators.

\subsection{Assessing Quality Education Provision on Learners}

Nevertheless, the question of addressing quality education was equally pursued in this research by assessing the following; classroom management in terms of teacher-pupil ratio, availability of teaching materials and quality teaching and teaching staff. The responses showed education quality still remained a challenge with the majority about $77 \%$ openly stating the school lacked adequate teaching materials. See responses below:

Table4.Do you have enough teaching materials in your class?

\begin{tabular}{|l|l|l|l|l|l|}
\hline \multicolumn{2}{|c|}{ Frequency } & \multicolumn{1}{|c|}{ Percent } & \multicolumn{1}{c|}{ Valid Percent } & \multicolumn{1}{c|}{ Cumulative Percent } \\
\hline \multirow{3}{*}{ Valid } & Yes & 3 & 21.4 & 21.4 & 21.4 \\
\cline { 2 - 6 } & No & 11 & 78.6 & 78.6 & 100.0 \\
\cline { 2 - 6 } & Total & 14 & 100.0 & 100.0 & \\
\hline
\end{tabular}

In separate interviews with the school administrators, they both lamented on lack of adequate teaching materials coupled with excessive numbers in classes. For example, below is a response from administrator for school B:

The school has a critical shortage of teaching materials, text books, chalk and sometimes we run out of chalk before end of term....teachers too complain about poor quality chalk board...

the numbers of pupils wanting places, you know being in town are also increasing every term.

\subsection{Evaluating the overall Impact of the School Feeding Program on Quality Education}

A set of question were outlined to assess participants' opinion on the impact of the program on quality education provision. While there was overwhelming endorsement on the program's impact on tackling absenteeism and performance, admittedly, there was a clear cut divide in opinion on quality education with half of the participants arguing it did and the other holding an opposed view. Arguably, it is easier to connect feeding and increased pupil attendance, but on the contrary it is rather difficult to connect the same pupil feeding with improved pupil performance. Performance can be a consequence of several factors at play as highlighted in literature review on what amounts to quality education. See responses in the table below:

Table5.Impact of Program on Quality Education

\begin{tabular}{|l|l|l|l|l|l|}
\hline \multicolumn{2}{|c|}{ Frequency } & \multicolumn{1}{|c|}{ Percent } & \multicolumn{1}{|c|}{ Valid Percent } & Cumulative Percent \\
\hline \multirow{3}{*}{ Valid } & Agree & 7 & 50.0 & 50.0 & 50.0 \\
\cline { 2 - 6 } & Disagree & 7 & 50.0 & 50.0 & 100.0 \\
\cline { 2 - 6 } & Total & 14 & 100.0 & 100.0 & \\
\hline
\end{tabular}


In fact, the sponsor of the feeding program despite respondingthat the program did addressthe problem of quality education, he was quick to mention that this was still a question of debate:

Note: quality education is a factor of many things...feeding only comes into the picture when other variables are available e.g. teachers, teaching and learning materials, good space for classes.

This section was all about demonstrating the research methods and instruments used as well as the findings of the study. It also covered a critical analysis of the findings and discussing in-depth the results.

\section{CONCLUSiON}

The research study started with a well demonstrated theoretical framework and explored in-depth the different literature in line with the research investigation. This was then linked to the methodological framework and justification of the research paradigm adopted. From the findings, it is crystal clear that the feeding program impacts a lot in tackling behavioral change of learners. It is a catch in attracting pupils to remain in school and to some extent help pupil participation in school activities. Nonetheless, the real impact on pupil performance cannot be exclusively alluded to the feeding program and this came out strongly in the findings. This is because pupil performance is a combination of a lot factors such which redefine quality education. Suffice to mention, that quality education stills remains a target yet to be achieved even though there is unanimous acknowledgement of the feeding program and its impact on behavioral change of leaners. Quality education is seemingly a fight that needs to be embraced and accomplished within the SDGs. This is in view of thecontinued inadequate teaching materials, inappropriate teacher-pupil ratio in many public schools thus compromising on overall quality education.

It is important that stakeholders like NGOs come on board to complement government's effort in providingEFA although it still remains government's responsibility to ensure quality education is provided to leaners through adequate provision of learning materials and a balanced teacher-pupil ratio. On the other hand, it has been observed donor funding projects raise the concern of sustainability. The previous experiences have shown that most of these projects die a natural death as soon as the sponsors pull out. Moyo (2010) has a point when she argues that donor aids have left a legacy of failure and unsustainability for African countries, but on the contrary this research has shown that education aid is still significant. However, the recommendations are that there must be a guiding framework for all aid funders to fit into government's education priorities and targets rather than the opposite as it has usually been the case in the past. It can almost be predicted of what would be the immediate repercussions if for example the school feeding program is curtailed. Againproblems of increased pupil absenteeism, pupil drop out would recur. Nonetheless, inasmuch as these complementally programs provide a suitable environment for learners, focus should be on achieving quality education for all in line with the post-2015 MDG on education. The findings from this study give insight into the sort of agendagovernment should seek to pursue to tackle the real problem of quality education and sustainability.

\section{REFERENCES}

[1] Abuya,B., Oketch, M. and Musyoka,P. 2013. Why do pupils dropout when education is 'free'? Explaining school dropout among the urban poor in Nairobi, Compare: A Journal of Comparative and International Education. [Online]. Vol. 43 (6), pp. 740-762. [25 May 2016]. Available from: DOI:10.1080/03057925.2012.707458

[2] Brundrett, M. 2014. Education for all: the challenges of achieving universal early childhood care and primary education, Education. International Journal of Primary, Elementary and Early Years Education. [Online] Vol. 42 (3), pp. 233-236, DOI: [23 October 2017]. Available from: 10.1080/03004279.2014.912911

[3] Barret, A., Sayed, Y., Schweisfurth, M. and Tikly, L. 2014. Learning, pedagogy and the post-2015 education and development agenda. International Journal of Educational Development. [Online] Vol. 40 2015), pp.231-236.[10 2016]. Available from: http://dx.doi.org/10.1016/j.ijedudev.2014.11.003

[4] CSPR, JCTR and CCJDP. 2005. The Cost of Meeting the MDGs in Zambia. (Draft Report), October 2005. Lusaka. 
Does School-Feeding Initiative Matter? An assessment of Its Impact on Quality Education and Positive Behavior Change of Learners in Primary Schools of Chipata District of Zambia

[5] Cohen,L., Manion,L. and Morrison,K. 2007. Research Methods in Education. (6 ${ }^{\text {th }}$ edn). New York. Routledge.

[6] Heyneman, S. P. 2003. "The History and Problems in the Making of Education Policy at the World Bank 1960-2000.” International Journal of Educational Development. Vol 23 (3), pp. 315-337.

[7] Jesuit Centre for Theological Reflection (JCTR). 2005. The cost of meeting the MDGs in Zambia.CAFOD and CIDSE. Lusaka.

[8] Kelly M.J. 1999. The Origins and Development of Education in Zambia: from Pre-colonial Times of 1996 : A Book of Notes and Readings. Image Publishers Limited. Lusaka.

[9] Miles, S. and Singal, N. 2010. The Education for All and inclusive education debate: conflict, contradiction or opportunity? International Journal of Inclusive Education. [Online]. Vol. 14(1), pp. 1-15. [20 September, 2017]. Available:http://dx.doi.org/10.1080/13603110802265125.

[10] Moyo, D. 2010. Dead Aid: Why Aid Makes Things Worse and How There is Another Way for Africa. London. Penguin Books Ltd.

[11] MOE (Ministry of Education). 2003. Ministry of education Strategic Plan 2003-2007. Ministry of Education. Lusaka. Zambia.

[12] Munteanu, C., Molyneaux, H., Maitland, J., McDonald, D., Leung, R., Fournier, H. and Lumsden,J. 2014. Hidden in plain sight: low-literacy adults in a developed country overcoming social and educational challenges through mobilelearning support tools. Pers Ubiquit Comput. [Online]. Vol. 8. Pp. 1455-1469 [23 October, 2017]. Available: DOI 10.1007/s00779-013-0748-x

[13] Ministry of Education. 1996. Educating our future: Ministry of Education Policy. Ministry ofEducation: Zambia.

[14] Pigozzi, M.J. 2008. Towards an index of quality education. Paper prepared for the International

[15] Working Group on Education (IWGE), June 2008.Available from:http://dx.doi.org/10.1080/03050068.2011.541682

[16] Punch, K. 2009. Research Methods in Education. London: Sage Publications

[17] Schweisfurth, M. 2014. Learner-centred pedagogy: Towards a post-2015 agenda for teaching and learning.International Journal of Educational Development. [Online]. Vol. 40 (2015), pp. 259-266. [10 October 2017]. Available from:http://dx.doi.org/10.1016/j.ijedudev.2014.10.011

[18] SACMEQ (Southern and Eastern Africa Consortium for Monitoring Education Quality) Report. 2011. Quality of Primary School Inputs in Zambia. [Online]. [22 October 2017]. Available from:www.sacmeq.org

[19] SACMEQ. 2007.A study of the conditions of schooling and the quality of education in Zambia. [Online]. [22 October 2017]. Available from: www.sacmeq.org.

[20] Subrahmanian, R. 2002. Engendering education: Prospects for a rights based approach tofemale education in India. In Gender justice, development, and rights.ed. M. Molyneuxand S. Razavi, 204-237. Oxford: Oxford University Press.

[21] Tungarazaa, F., Sutherland, M. and Stack, N. 2013. Universal education or open education opportunities for all? Compare: A Journal of Comparative and International Education. [Online]. Vol. 43(6), pp. 822824. [27 October 2017]. www.tandfonline.com/loi/ccom20

[22] UNICEF. 2013. The State of the world for children 2013. [Online]. [23 October 2017]. Available from: http://www.unicef.org/sowc2013/report.html

[23] United Nations. 1948. The universal declaration of human rights. http://www.un.org/en/documents/udhr/ (accessed October 1, 2017).

[24] United Nations (UN). 1989. Convention on the Rights of the Child, ratified by General Assembly of the United Nation in resolution 44/25 of 20 November 1989.http://www.un.org/ en/documents/udhr/ (accessed October 1, 2017).

[25] United Nations. 2015. "Transforming our world: The 2030 Agenda for Sustainable Development". New York. UN

[26] United Nations Development Programme (UNDP). 2016. Human Development Report 2016. New York. UNDP.

[27] Unterhalter, E. 2014. Measuring Education for the Millennium Development Goals: Reflections on Targets, Indicators, and a Post-2015 Framework. Journal of Human Development and Capabilities. [Online]. Vol. 15 (2-3), pp. 176-187. [21 September, 2017]. Available from DOI: $10.1080 / 19452829.2014 .880673$. 
Does School-Feeding Initiative Matter? An assessment of Its Impact on Quality Education and Positive Behavior Change of Learners in Primary Schools of Chipata District of Zambia

[28] Verger,A., Sayed,Y., Hiroshi,I., Croso,C. and Beardmore,S. 2012. EFA, civil society and the post-2015 agenda, Compare: A Journal of Comparative and International Education. 42:6, 881-902, DOI: 10.1080/03057925.2012.729319

[29] To link to this article: http://dx.doi.org/10.1080/03057925.2012.729319

[30] Waage, J., Banerji, J., Campbell, O., Chirwa, E., Collender, G., Dieltiens, V., Dorward, A. et al. 2010. "The Millennium Development Goals: A Cross Sectoral Analysis and Principles for Goal Setting Post 2015." The Lancet.Vol. 376 (9745), pp. 991- 1023.

\section{AUTHOR'S BIOGRAPHY}

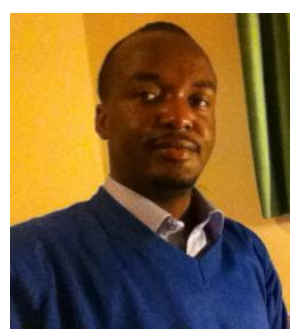

John Zimba holds a B.A ED. with major in Geography and Psychology from the University of Zambia in 2009. He is a 2016 postgraduate in MSc Educational Policy with focus on Young People, Social Inclusion and Change with a distinction from University of Glasgow in the UK. He has 8 years of secondary teaching experience and currently teaches at Anoya Zulu Secondary School as class teacher. $\mathrm{He}$ is author of this research article and looks forward to using research publications fordiscourse on contemporary issues withinEducation.

Citation:John Zimba. "Does School-Feeding Initiative Matter? An assessment of Its Impact on Quality Education and Positive Behavior Change of Learners in Primary Schools of Chipata District of Zambia". International Journal of Humanities Social Sciences and Education (IJHSSE), vol 5, no. 5, 2018, pp. 75-83. doi: http://dx.doi.org/10.20431/2349-0381.0505010.

Copyright: (C) 2018 Authors. This is an open-access article distributed under the terms of the Creative Commons Attribution License, which permits unrestricted use, distribution, and reproduction in any medium, provided the original author and source are credited. 